\title{
Student Evaluation of Online Teaching Quality, Their Own Engagement and Success Expectancy in the Future Profession
}

\author{
https://doi.org/10.3991/ijet.v17i04.27517 \\ Tomislava Vidić1 $\left.{ }^{\bowtie}\right)$, Irena Klasnić ${ }^{2}$, Marina Đuranović \\ ${ }^{1}$ Primary school Remete, Zagreb, Croatia \\ ${ }^{2}$ Faculty of Teacher Education, University of Zagreb, Zagreb, Croatia \\ tomislava.vidicezg.t-com.hr
}

\begin{abstract}
The aim of this research was to examine students' perceptions of online teaching, their own engagement and abilities, and their success expectancy in the future profession. 713 students attending the University of Zagreb, Croatia, took part in the research. The results indicate that students spend an average of 6 hours studying per day. Statistically significant differences were identified in students' perceptions of the way in which the teaching process was conducted, support provided by professors and the engagement of students in terms of the time they spend in organized and independent studying. Students who study less than 5 hours per day tend to give lower rating to the quality of the teaching process and their own engagement. Students who study more than 6 hours per day tend to give lower rating to the support provided by professors. Regression analysis revealed that the perceptions of the way in which the online teaching process was organized and conducted, of the abilities, engagement and hope significantly contribute to the interpretation of success expectancy in the future profession. Students' age was not found to be a significant predictor.
\end{abstract}

Keywords - COVID-19, future professional success, higher education, hope, online learning

\section{Introduction}

Towards the end of 2019 and at the beginning of 2020, the world was threatened by SARS-CoV-2, a new, unknown virus, which causes serious respiratory infections in humans. In order to prevent the spread of the disease, strict measures were introduced all around the world, such as limiting the freedom of movement, keeping social distance, introducing quarantine, and closing numerous public, cultural and educational institutions. According to data provided by OECD [1], almost 150 countries around the world closed their schools trying to prevent the virus from spreading. Almost all education systems were trying to find various ways to continue with teaching during the pandemic [2]. They resorted to digital technology, which led to the beginning of distance teaching, in various ways: online, on educational platforms; in virtual classrooms, on TV channels. In spite of the initial setbacks, after facing the first challenges, it was 
evident that the crisis spurred innovations in the education domain, which have had a great impact on the course of learning, innovation and digitalization [3].

Distance teaching is not an entirely new model of education, despite the common belief [4]. Scientific literature contains some notions which are similar in definitions, but which are still different. These include: m-learning, e-learning, virtual education, online education, etc. All these notions are in fact diverse online teaching tools, differing in methods or systems they require [5]. It is important to note that distance teaching has had a long history and that it has undergone significant transformations since its early beginnings.

This research was conducted in order to examine perceptions of students, future teachers, of the way in which online teaching was organized during the pandemic, their own engagement in the studies, success expectancy in their future profession and hopes they have in general.

\section{$2 \quad$ Literature review}

During the COVID-19 pandemic, universities across the world transferred to online teaching due to lockdowns. However, this has created numerous problems and challenges. The immediate problems included the inability to access the Internet, mental stress and uncertainty caused by the COVID-19 pandemic [6].

Apart from that, both students and teachers found themselves in new, unfamiliar situations and teaching and learning conditions. Online teaching requires diverse skills - pedagogical, technical, communication and design [7]. The teachers who were not skilled in using online platforms had to spend more time planning the lessons, while students were expected to learn more independently [8]. The teachers assumed some new roles which they were expected to play well. They were supposed to become good lesson planners and to make clear plan of online teaching; coaches who teach students how to learn; facilitators who provide students with opportunities to show their creativity, and communicators who deliver the teaching content effectively [9]. They were expected to be good motivators, because it was necessary for students to have a high level of motivation in order to make online teaching successful [10].

Some teachers were not ready for online teaching, but there were also students without sufficiently developed digital competences. For them, it was difficult to manage the work process during online teaching. According to the results of research carried out on a sample of 1,500 students attending the undergraduate studies at Arizona State University, the students indicated they were less inclined to online teaching, while $50 \%$ of them stated they spent less time studying than before [11].

In order to do the tasks successfully, it was necessary to be engaged in work. In the context of studying, study engagement is the equivalent of work engagement [12]. Bond et al. [13] define student engagement as energy and effort that students employ within their learning community, observable via any number of behavioural, cognitive or affective indicators across a continuum. Student engagement indicators are participation in activities, good exam results, time spent working on the tasks and success [14]. Stu- 
dents characterized by a high level of engagement in the studies are persistent in demanding activities, focused, they perform their tasks on time, are curious, flexible, they ask questions for clarification of ideas, use various learning strategies and self-regulation to support learning [12], [15], [16]. Study engagement in is in a positive relationship with learning and academic achievement [17], [18], lower depression rate and substance use [19], while lack of engagement is related to student dropout rate in both secondary school and higher education [15]. The transfer to online teaching revealed that student engagement posed a challenge to achieving the desired teaching quality [20].

In the living conditions imposed by the pandemic, when health was emphasized as the most important priority, the teaching process was conducted online. However, there are fears that achieving the planned teaching outcomes was not the priority. Furthermore, there is uncertainty whether there would be negative implications on the students performing their professional tasks in the future. Professional success is important in the teaching career, like in any other career. Interest of the scintific circles in professional success of teachers stems from its importance for the current trends in education reform, which require teachers to be trained as highly skilled professionals, able to perform professional activities within the context of dynamics of educational institutions oriented towards development and self-development of students [21].

Hope, optimism and interest in the future comprise cognitive, emotional and motivational attitude to the future. This kind of relationship includes thinking about the future and having expectations that the desired course of events will take place, but with effort invested and belief in the achievability of goals. Individuals full of hope and optimism believe that their way of work needs to lead to excellent results, have a clear picture of the future they desire, have a detailed plan about their own activities in the following few years, and are optimistic about the future, despite the obstacles. There are by no means differences between the notions of hope and optimism, but they overlap to a significant degree. Hope is a more emotional, while optimism is a more cognitive cathegory [22].

Children and young people who evaluate themselves positively exhibit higher levels of hope [23], [24]. Hope and self-respect have proved to be protective factors of development, especially in unfavorable living conditions [25]. Snyder et al. [26] claim that individuals who have a higher level of hope in stressful situations find more strategies to face stress and are more efficient in employing these strategies. Research results show that hope and optimism are predictors of many favorable outcomes: achievements at all levels (school, sports, professional), good social relationships and mental health [27]. Hope protects an individual from negative thoughts and emotions, and is therefore crucial for psychological well-being [28].

\section{$3 \quad$ Research question}

The main aim of this research was to examine students' perceptions of online teaching, their own engagement and abilities, as well as their success expectancy in the chosen profession. 
To reach the research aim, the following research questions were set:

1. Is there a difference in perceptions of the characteristics of online teaching, own abilities and engagement, hopes and success expectancy in relation to the time spent studying?

2. To what extent do characteristics of online teaching, perceptions of students' own abilities and engagement, hopes and time spent studying contribute to the interpretation of success expectancy in the future profession?

We hypothesized that students who spend more time studying and who participate in online teaching tend to give a more positive rating to the characteristics of online teaching and are more confident in their own success in the future profession. Similar to that, it is assumed that the interpretation of success in the future profession will significantly depend on a student's own engagement, abilities, hope, time spent studying, and perception of online teaching.

\section{$4 \quad$ Methodology}

\subsection{Participants}

The total number of respondents in this research was 713 students of the University of Zagreb. $84.3 \%$ were females $(n=601)$, while $15.7 \%$ were males $(n=112)$. Students participating in the research were attending all years of study - from the first to the fifth, i.e. last year of study. $20.9 \%$ were first-year students $(n=149), 18.4 \%$ were second-year students $(n=131), 18.5 \%$ were third-year students $(n=132), 28.1 \%$ were fourth-year students $(n=200)$ and $14.2 \%$ were fifth-year students $(n=101)$. Their age range was $18-34$ years, while their average age was $22.14(S D=2.30)$.

With regard to the form of online questionnaire, it was possible to submit it only if all items had been estimated, so there were no incomplete questionnaires. Additional control did not identify any extreme values (extreme outliers), but some deviations were found (outliers). By examining each respondent's data which exhibited deviations it was determined that the data corresponded to the context of other answers, and could therefore not be considered deviations. That is why all 713 respondents were included in data processing.

\subsection{Measures}

Online questionnaire consisted of individually grouped items which encompassed the evaluation of the teaching organization and teaching quality, support received from professors, students' own abilities, engagement and success expectancy in the future profession. Apart from that, Hope questionnaire [26] was applied, and data on gender, year of study, respondents' age and the number of hours spent studying were collected.

Organization of teaching. encompassed five items through which the respondents evaluated the regularity and the quality of teaching. This is an example of an item: 
Online teaching at my faculty is organized in an excellent way. The calculated reliability coefficient for organization of teaching is $\alpha=.717$.

Support contains 4 items used to evaluate the support received from professors. An example: I can turn to professors if I come across a problem; My professors reply to my questions regularly. The calculated reliability coefficient is $\alpha=.845$.

Implementation of the teaching process consists of 5 items used to examine students' perceptions of how interesting the teaching process was, delivery of the teaching content and the way in which the teaching content was delivered. An example: My professors are trying hard to make the teaching process as interesting as possible. The calculated reliability coefficient is $\alpha=.797$.

Students' own abilities contains 5 items which respondents used to evaluate their own abilities for using the technology, for multitasking and work on a computer in general. An example: I am very skillful in using the technology I need to participate in online lectures. The calculated reliability coefficient is $\alpha=.663$.

Students' own engagement was evaluated by the respondents using 5 items which included regularity and participation in the teaching process. An item example (recoded): During online lectures I often do something else. The calculated reliability coefficient is $\alpha=.770$.

Success expectancy in the future profession was estimated using 3 items, such as: $I$ am convinced that someday I will be successful in my profession. The calculated reliability coefficient is $\alpha=.756$.

Hope questionnaire [26] contains 8 items and originally measures two dimensions (pathways and agency), but the results of the performed explanatory factor analysis indicated clearly only one factor, according to the Kaiser-Guttman criterion. KMO was 0.91 , indicating that the sampling was valid and that the obtained data are in line with factor analysis. Bartlett's homogeneity test of variance indicates that variance is equal for all samples $\left(X^{2}=2730.6 ; d f=28 ; p<.01\right)$. The proportion of the variance explained is $57.16 \%$, and only one characteristic root has value over $1-4.573$. Cronbach's $\alpha$ coefficient of reliability is high, with value $\alpha=.89$.

The respondents evaluated all items on a 5-point Likert scale: from 1 - I completely disagree, to 5 - I completely agree.

Estimation of time spent studying and participating in online lectures was carried out using two questions: How much time, on average, do you spend on online lessons per day? and How much time, on average, do you spend studying independently (apart from online lessons) every day? The respondents were offered answers ranging from 0 to 10 hours per day and more than 10 hours per day.

\subsection{Procedure}

Students at the University of Zagreb (Croatia) who attend some of the teacher education faculties were invited to participate in the research. They were approached via the Merlin E-learning platform, which is the first official platform for communication between students and professors. The respondents filled out the questionnaire voluntarily and anonymously, and no compensation was awarded to any participants who completed the survey. 


\subsection{Data analysis}

The collected data were analysed using the statistical software SPSS 23.0. Explanatory factor analysis was performed on the Hope questionnaire and $\alpha$ coefficients of reliability were calculated for all variables. Descriptive statistics was used to determine the levels of perception of online teaching and hope. The one-way ANOVA was applied to examine the differences in perceptions in terms of the time spent studying. The Bonferroni correction of the treshold value of the significance of the results was performed. In order to determine the effect size of differences, partial eta squared was calculated, as well as Cohen $d$ coefficient to compare all the pairs. A hierarchical regression analysis was performed for the criterion variable success expectancy.

\section{$5 \quad$ Results}

Descriptive statistics for all analysed constructs is presented in Table 1. Although some distributions depart statistically significantly from the Gaussian distribution, the asymetric and kurtosis values do not exceed treshold values of 3 and 10 [29]. The sample is large enough and it is statistically justified to use parametric procedures in further analyses.

Table 1. Descriptive statistics for the variables of the study $(N=713)$

\begin{tabular}{|l|c|c|c|c|c|c|}
\hline \multicolumn{1}{|c|}{ Variable } & $\boldsymbol{M}$ & $\boldsymbol{S D}$ & $\boldsymbol{M i n}$ & Max & Skewness & Kurtosis \\
\hline Organization & 2.52 & 0.64 & 0.80 & 4.00 & -0.05 & -0.52 \\
\hline Support & 3.80 & 0.82 & 1.00 & 5.00 & -0.57 & 0.06 \\
\hline Implementation & 3.55 & 0.80 & 1.00 & 5.00 & -0.28 & -0.16 \\
\hline Abilities & 3.61 & 0.70 & 1.00 & 5.00 & -0.25 & 0.03 \\
\hline Engagement & 2.96 & 0.91 & 1.00 & 5.00 & 0.12 & -0.51 \\
\hline Success expectancy & 3.76 & 0.86 & 1.00 & 5.00 & -0.49 & -0.01 \\
\hline Hope & 3.95 & 0.68 & 1.25 & 5.00 & -0.69 & 0.62 \\
\hline
\end{tabular}

The obtained descriptive data (Table 1) indicate that respondents gave highest rating to dimensions of hope, perceived support and success expectancy in the future profession, while their perceptions of online teaching organization and their own engagement in online classes were given lower rating. The results obtained for the time spent studying show that the respondents spend 3.47 hours participating in online classes $(S D=$ $1.59)$ and somewhat less time studying independently $(M=2.59 ; S D=1.75)$. Altogether, on average they spend 6.05 hours studying.

The aim of this research was to determine if there are differences in perceptions of the examined variables in terms of the time students spend studying. Based on the obtained values, the sample was divided into three groups: Group A, made up of students who spend less than 5 hours per day studying and participating in online classes; Group $\mathrm{B}$, consisting of students who spend an average of 5 to 6 hours per day studying and participating in online classes, and Group C, consisting of students who spend more than 6 hours per day studying and participating in online classes. 
To examine the differences between the groups, the one-way analysis of variance was applied. In order to avoid the risk of Type 1 error due to a range of ANOVA tests, the Bonferroni correction was performed. For each dependent variable, 6 differences were calculated among each group, so $p$ value of at least 0.016 for $5 \%$ of risk and 0.003 for $1 \%$ of risk is considered significant. The results obtained with the one-way analysis of variance are presented in Table 2.

Table 2. Results of a one-way ANOVA examining the differences between group with regard to time spent studying $(N=713)$

\begin{tabular}{|c|c|c|c|c|c|c|c|c|}
\hline & $\mathbf{A}$ & B & $\mathbf{C}$ & & & & & \\
\hline Variable & $\mathrm{M}(\mathrm{SD})$ & $\mathrm{M}(\mathrm{SD})$ & $\mathrm{M}(\mathrm{SD})$ & $\begin{array}{c}F \\
(2,697)\end{array}$ & $\mathrm{p}$ & $\eta \mathrm{p} 2$ & \multicolumn{2}{|c|}{ Cohen's d } \\
\hline \multirow{2}{*}{ Organization } & 2.45 & 2.61 & 2.51 & \multirow{2}{*}{3.465} & \multirow{2}{*}{.032} & \multirow{2}{*}{.010} & & \\
\hline & $(0.61)$ & $(0.63)$ & $(0.65)$ & & & & & \\
\hline \multirow{2}{*}{ Support } & 3.80 & 3.99 & 3.69 & \multirow{2}{*}{8.361} & \multirow{2}{*}{$.001^{* *}$} & \multirow{2}{*}{.023} & \multirow{2}{*}{$\mathrm{B}-\mathrm{C}$} & \multirow{2}{*}{-0.37} \\
\hline & $(0.81)$ & $(0.73)$ & $(0.85)$ & & & & & \\
\hline \multirow{2}{*}{ Implementation } & 3.44 & 3.68 & 3.55 & \multirow{2}{*}{4.801} & \multirow{2}{*}{$.008^{*}$} & \multirow{2}{*}{.014} & \multirow{2}{*}{ A-B } & \multirow{2}{*}{0.31} \\
\hline & $(0.81)$ & $(0.70)$ & $(0.84)$ & & & & & \\
\hline \multirow{2}{*}{ Abilities } & 3.65 & 3.64 & 3.56 & \multirow{2}{*}{1.051} & \multirow{2}{*}{.350} & \multirow{2}{*}{.003} & & \\
\hline & $(0.67)$ & $(0.69)$ & $(0.72)$ & & & & & \\
\hline \multirow{2}{*}{ Engagement } & 2.55 & 3.04 & 3.16 & \multirow{2}{*}{31.643} & \multirow{2}{*}{$.001^{* *}$} & \multirow{2}{*}{.083} & A-B & 0.55 \\
\hline & $(0.87)$ & $(0.92)$ & $(0.83)$ & & & & A-C & 0.72 \\
\hline \multirow{2}{*}{ Success expectancy } & 3.62 & 3.84 & 3.79 & \multirow{2}{*}{3.749} & \multirow{2}{*}{.024} & \multirow{2}{*}{.011} & & \\
\hline & $(0.88)$ & $(0.80)$ & $(0.88)$ & & & & & \\
\hline \multirow{2}{*}{ Hope } & 3.89 & 3.92 & $4.01)$ & \multirow{2}{*}{2.072} & \multirow{2}{*}{.127} & \multirow{2}{*}{.006} & & \\
\hline & $(0.73)$ & $(0.66)$ & $(0.64)$ & & & & & \\
\hline
\end{tabular}

Note. Group A - time spent studying $\leq 4 \mathrm{~h}(n=206)$; Group B - time spent studying - 5 to $6 \mathrm{~h}(n=215)$; Group C - time spent studying $>6 \mathrm{~h}(n=279)$

${ }^{*} p<.05 ;{ }^{* *} p<.01$

The results show that there are statistically significant differences among the respondents only in dimensions of the perceived support, evaluation of online teaching and their own engagement. As was expected, the respondents who spend between 5 and 6 hours studying every day, as well as those who spend more than 6 hours studying, rate their own engagement higher than the respondents who spend less than 5 hours studying every day. However, the respondents who study between 5 and 6 hours every day show statistically significant differences in comparison to those who spend more time studying in terms of the support received from professors. Similar to that, there are statistically significant differences between the respondents - those who study between 5 and 6 hours every day rated the quality of online teaching implementation higher than those who spend more than 6 hours studying every day. In other examined dimensions, no statistically significant differences were detected, so the initial hypothesis can be accepted only partially.

The following task in the research was to check to what extent the examined variables contribute to the interpretation of the perception of success in the future profession. 
A two-step hierarchical regression analysis was performed (Table 3). Respondents' age was added in the first step, while in the second step, the following were added: organization of online teaching, implementation, support, abilities, engagement, hope and number of hours spent studying. Table 3 shows regression analysis results, which provide information on regression coefficient $\mathrm{R}=.714$, that is, on $51 \%$ of the explained variance of success expectancy based on the given predictors.

Table 3. Hierarchical regression analysis results predicting success expectancy in the future profession $(N=713)$

\begin{tabular}{|c|c|c|c|c|}
\hline Predictor & $\Delta \mathbf{R}^{2}$ & $\boldsymbol{\beta}$ & $\mathbf{t}$ & $\mathbf{p}$ \\
\hline \multicolumn{5}{|l|}{ (1) } \\
\hline Age & & .15 & $3.940^{* *}$ & .001 \\
\hline \multicolumn{5}{|c|}{$\mathrm{R}=0.15 ; \mathrm{R} 2=0.02 ;$ Adjusted $\mathrm{R} 2=0.02 ; \Delta \mathrm{F}(1 / 698)=15.526 ; \mathrm{p}<.001$} \\
\hline (2) & $.49^{* *}$ & & & \\
\hline Organization & & .23 & $6.354^{* *}$ & .001 \\
\hline Support & & .02 & 0.572 & .568 \\
\hline Implementation & & .20 & $5.014^{* * *}$ & .001 \\
\hline Abilities & & .10 & $3.451^{* *}$ & .001 \\
\hline Engagement & & .20 & $5.907^{* *}$ & .001 \\
\hline Hope & & .29 & $9.866^{* *}$ & .001 \\
\hline No. of hours spent studying & & -.03 & -1.143 & .254 \\
\hline \multicolumn{5}{|c|}{$\mathrm{R}=0.715 ; \mathrm{R} 2=0.51 ;$ Adjusted $\mathrm{R} 2=0.51 ; \Delta \mathrm{F}(7 / 691)=98.700 ; \mathrm{p}<.001$} \\
\hline
\end{tabular}

Respondents' age proved to be a statistically significant predictor. $2.2 \%$ of success expectancy variance and correlation analysis indicate that success expectancy increases with age $(r=.15 ; N=700 ; p<.01)$. In the second step, other variables were added, and the percentage of the explained variance increased for $48.9 \%$ - to $51.1 \%(R=.715)$. An increase in the percentage of the explained variance is statistically significant. Statistically significant predictors are organization, implementation, abilities, engagement and hope. Support and number of hours spent studying do not have a significant independent contribution to the interpretation of success expectancy. Additional analyses show that this step helps reduce the proportion of the explained variance from the first step of regression analysis, and here the respondents' age explains only $0.5 \%$ of success expectancy variance. The largest proportion of $13.6 \%$ is explained by hope, $11.4 \%$ by organization, $10.6 \%$ by engagement, $10.5 \%$ by implementation, $4 \%$ by abilities, while less than $1 \%$ of variance is explained by support and studying.

\section{Discussion}

Vast research conducted so far indicates that the regular teaching process, which had been implemented before the COVID-19 pandemic, was of higher quality and more efficient than the teaching process implemented during the last year. However, taking 
into consideration how long the pandemic has lasted and that it might continue in the future, it is important to know which segments of online teaching process the students are satisfied with and which require adjustments. The analysis of the obtained mean values for the examined variables shows that students rated highest their own sense of hope, success expectancy and their own abilities, while they rated the characteristics of online teaching somewhat lower. The students are more satisfied with the implementation than with organization of online teaching, while they gave the highest rating to the support they received from professors. Many professors would like to know whether the implemented online teaching process had achieved the planned outcomes, and can we, as a society, expect to have successful professionals in the future. The results of this research indicate that students, although to a certain extent dissatisfied with the organization of online teaching, still have high success expectancy in the future profession. $50.4 \%$ of the respondents believe that the knowledge they have gained during online teaching will be useful to them in their future work, while $85.5 \%$ of the respondents believe that they will be successful in their future profession.

However, apart from success expectancy, success implies certain engagement and time invested in studying. In this research it was revealed that students spend an average of 6 hours participating in online lessons and in independent studying, which amounts to 30 hours per week. Although it may seem that this number is insufficient, earlier research has shown that there are certain trends in decrease of the time spent studying. As stated in [30], in the 1960s students used to spend 40 hours per week studying, while in 2003 the number decreased to 13 hours per week. Only $44 \%$ of students stated they studied more than 20 hours per week. There is a certain agreement between authors that faculties spend less time on teaching and mentoring students [31], [32]. As stated [32], despite the fact that student invest less effort, they get high marks; namely, lower student activity enables less mentoring provided by professors. The author points out that "There seems to be a breakdown of shared responsibility for learning - on the part of faculty members who allow students to get by with far less than maximum effort, and on the part of students who are not taking full advantage of the resources institution provide" [32, p. 28]. Examination of the differences in perceptions of online teaching with regard to time spent studying has shown in this research that students differ only in perceptions of support, implementation of the teaching process and their own engagement. As expected, students who spend more than 6 hours studying tend to give their engagement statistically significantly higher rating than students who study less than 5 hours per day. Students who spend less than 5 hours studying per day tend to give lower rating to the quality of the teaching process. It can be assumed that their dissatisfaction with the implementation of the teaching process is the reason why they spend less time in active participation in online teaching, since they believe they cannot benefit from it. These results are to a certain extent expected, but it is surprising that students who actively participate in the teaching process and who spend most time studying independently tend to give lowest rating to the support received from professors. It can be assumed that they rely more on their own work and studying precisely because of the perception that professors do not provide them with sufficient support. It is interesting to note that students who spend most time studying tend to give lower rating 
to their own abilities than is the case with other students, although no statistically significant differences were detected. It might be due to the low rating of the perceived support and their own abilities that these students exhibit more persistence in their work and invest more effort in fulfilling their obligations in order to be able to achieve the set goals.

The following research task was to determine to what extent the examined variables contribute to the interpretation of success expectancy in the future profession. Data analysis shows that the most significant predictors with highest proportion in the interpretation of success expectancy in the future profession are hope, organization of online teaching, student engagement and implementation of online teaching. Significant predictors with lower contribution to the interpretation of success are perceptions of students' own abilities, support provided by professors and time spent studying. It is well known that people achieve the set goals more easily if they have a high level of hope. People with a high level of hope have more positive than negative thoughts per day. That is why hope is useful at the time of collective efforts to curb the COVID-19 pandemic. Previous longitudinal research has shown that students with pronounced hope have better academic achievements [33], which has been confirmed by the conducted meta-analysis of research on hope and student success [34]. Hope itself incorporates strategies for goal achievement, as well as motivation to persist in the process of achieving one's goals. However, it was found that apart from hope, success expectancy can be affected by organization and implementation of online teaching, as well as student engagement. Therefore, it can be assumed that students' beliefs that they would be successful in the future profession are also positively influenced by the content and methods of teaching that professors employ. The efforts of professors to adapt the teaching content to students' needs in their future work probably help students feel they are well prepared and trained for most of their future work and problems they will face. The results obtained in this research suggest that studying and support provided by professors have lower contribution to the interpretation of future success. It can be assumed that students who participated in this research tend to believe that achieving success does not necessarily involve studying, but other components. Although numerous characteristics account for one's future success, hard work and effort invested in achieving success cannot be replaced by anything. However, it should be pointed out that earlier research found the relationship between support, i.e. teacher's feedback and the time a student spent studying [35]. It was shown that students who received prompt and regular feedback from the professor about their performance using online learning technology had higher outcome expectations, reported a higher level of mastery, and spent more hours per week using the technology than students who did not get such feedback. Therefore, more frequent and quality communication between students and professors would be useful.

\section{Conclusion}

The present study examined students' perceptions of online teaching, engagement, abilities, success expectancy in the chosen profession, and hope. Online teaching has 
become an essential part of studying, and both professors and students have been facing its challenges. This research offers preliminary identification and understanding of the position of students in the online teaching environment, as well as possibilities for designing a more quality university teaching proess. The obtained results suggest that, from students' perspective, there are segments which should be improved, which should be an incentive for university bodies to try to respond more efficiently to the challenges posed by the pandemic.

\section{References}

[1] A. Schleicher, "OECD Education and Skills Today," 1. 4. 2020. [Online]. Available: https://oecdedutoday.com/coronavirus-education-digital-tools-for-learning/

[2] T. Sari and F. Nayır, "Challenges in Distance Education During the (Covid-19) Pandemic Period," Qualitative Research in Education, vol. 9, no. 3, pp. 328-360, 2020. https:// doi.org/10.17583/qre.2020.5872

[3] B. P. Sahoo, A. Gulati and I. Ul Haq, "Covid 19 and Challenges in Higher Education: An Empirical Analysis," International Journal of Emerging Technologies in Learning, vol. 16, no. 15, pp. 210-225, 2021. https://doi.org/10.3991/ijet.v16i15.23005

[4] T. J. Clark, "Distance education," in Clinical Engineering Handbook (2nd ed.), London: Elsevier - Academic Press, 2020, pp. 410-415. https://doi.org/10.1016/B978-0-12-8134672.00063-8

[5] M. Ally, "Foundations of educational theory for online learning," in The Theory and Practice of Online Learning (2nd Ed.), T. Anderson, Ed., Edmonton: AU Press, 2008, pp. 15-44.

[6] S. Sharma and A. Bumb, "The Challenges Faced in Technology-Driven Classes During COVID-19," International Journal of Distance Education Technologies, vol. 19, no. 1, pp. 17-, 2021. https://doi.org/10.4018/IJDET.20210101.oa2

[7] N. M. Almusharraf and S. H. Khahro, "Students' Satisfaction with Online Learning Experiences During the COVID-19 Pandemic," International Journal of Emerging Technologies in Learning, vol. 15, no. 21, pp. 246-267, 2020. https://doi.org/10.3991/ijet.v15i21.15647

[8] V. Amnouychokanant, S. Boonlue, S. Chuathong and K. Thamwipat, "Online Learning Using Block-based Programming to Foster Computational Thinking Abilities during the COVID-19 Pandemic," International Journal of Emerging Technologies in Learning, vol. 16, no. 13, pp. 227-247, 2021. https://doi.org/10.3991/ijet.v16i13.22591

[9] B. P. Heuer and K. P. King, "Leading the Band: The Role of the Instructor in Online Learning for Educators," The Journal of Interactive Online Learning, vol. 3, no. 1, pp. 1-11, 2004. https://www.ncolr.org/issues/jiol/v3/n1/leading-the-band-the-role-of-the-instructor-inonline-learning-for-educators.html

[10] M. Deimann and T. Bastiaens, "The Role of Volition in Distance Education: An Exploration of its Capacities," International Review of Research in Open and Distance Learning, vol. 11, no. 1, pp. 1-16, 2010. https://doi.org/10.19173/irrodl.v11i1.778

[11] E. M. Aucejo, J. French, M. P. U. Araya and B. Zafar, "The impact of COVID-19 on student experiences and expectations: Evidence from a survey," Journal of Public Economics, vol. 191, p. 104271, 2020. https://doi.org/10.1016/j.jpubeco.2020.104271

[12] I. Černja Rajter, Z. Galić, I. Kuzman and I. Šverko, "Odrednice i ishodi angažiranosti u studiju [Antecedents and Outcomes of Students' Engagement]," Društvena istraživanja, vol. 28, no. 4, pp. 607-625, 2019. https://doi.org/10.5559/di.28.4.03 
Paper - Student Evaluation of Online Teaching Quality, Their Own Engagement and Success...

[13] M. Bond, K. Buntins, S. Bedenlier, O. Zawacki-Richter and M. Kerres, "Mapping research in student engagement and educational technology in higher education: a systematic evidence map," International Journal of Educational Technology in Higher Education, vol. 17, no. 2, pp. 1-30, 2020. https://doi.org/10.1186/s41239-019-0176-8

[14] M. F. Sinclair, C. M. Hurley, D. L. Evelo, S. L. Christenson and M. L. Thuelow, "Making connections that keep students coming to school," in Preventing problem behaviors: A handbook of successful prevention strategies, B. Algozzine and P. Kay, Eds., Thousand Oaks: Corwin Press, 2002, pp. 162-182.

[15] J. D. Finn and K. S. Zimmer, "Student Engagement: What Is It? Why Does It Matter?," in Handbook of Research on Student Engagement, Boston, MA: Springer, 2012, pp. 97-131. https://doi.org/10.1007/978-1-4614-2018-7_5

[16] J. A. Fredricks, P. C. Blumenfeld and A. H. Paris, "School engagement: Potential of the concept, state of evidence," Review of Educational Research, vol. 74, pp. 59-109, 2004. https://doi.org/10.3102/00346543074001059

[17] J. A. Fredricks, M. Filsecker and M. A. Laws, "Student engagement, context, and adjustment: Addressing definitional, measurement, and methodological issues," Learning and Instruction, vol. 43, pp. 1-4, 2016. https://doi.org/10.1016/j.learninstruc.2016.02.002

[18] H. Lei, Y. Cui and W. Zhou, "Relationships between student engagement and academic achievement: A meta-analysis," Social Behavior and Personality, vol. 46, no. 3, p. 517-528, 2018. https://doi.org/10.2224/sbp.7054

[19] M.-T. Wang and J. A. Fredricks, "The Reciprocal Links Between School Engagement, Youth Problem Behaviors, and School Dropout During Adolescence," Child Development, vol. 85, no. 2, p. 722-737, 2014. https://doi.org/10.1111/cdev.12138

[20] F. Farooq, F. A. Rathore and S. N. Mansoor, "Challenges of Online Medical Education in Pakistan During COVID-19 Pandemic," Journal of the College of Physicians and Surgeons Pakistan, vol. 30, no. 2, pp. S67-S69, 2020. https://doi.org/10.29271/jcpsp.2020.Supp1.S67

[21] T. Skoryk and N. Grytsyk, "Theoretical analysis of the factors influencing modern teachers' professional success," Scientific Journal of Polonia University, vol. 38, no. 1-2, pp. 209213, 2020. https://doi.org/10.23856/3868

[22] D. Miljković, M. Đuranović and T. Vidić, Odgoj i obrazovanje - iz teorije u praksu [Education - from theory to practice], Zagreb: IEP-D2, UFZG, 2019.

[23] M. Merkaš and A. Brajša-Žganec, "Children with Different Levels of Hope: Are There Differences in Their Self-esteem, Life Satisfaction, Social Support, and Family Cohesion?," Child Indicators Research volume, vol. 4, pp. 499-514, 2011. https://doi.org/10.1007/ $\underline{\mathrm{s} 12187-011-9105-7}$

[24] S. S. Wong and T. Lim, "Hope versus optimism in Singaporean adolescents: Contributions to depression and life satisfaction," Personality and Individual Differences, vol. 46, no. 5-6, pp. 648-652, 2009. https://doi.org/10.1016/j.paid.2009.01.009

[25] Z. Raboteg-Šarić, A. Brajša-Žganec and M. Šakić, "Life satisfaction in adolescents: the effects of perceived family economic status, self-esteem and quality of family and peer relationships," Društvena istraživanja, vol. 18, no. 3, pp. 547-564, 2009. https://hrcak. srce.hr/39007

[26] C. R. Snyder, C. Harris, J. R. Anderson, S. A. Holleran, L. M. Irving, S. T. Sigmon, L. Yoshinobu, J. Gibb, C. Langelle and P. Harney, "The will and the ways: development and validation of an individual-differences measure of hope," Journal of Personality and Social Psychology, vol. 60, no. 4, pp. 570-585, 1991. https://doi.org/10.1037//0022-3514.60.4.570

[27] G. M. Buchanan and M. E. P. Seligman, Explanatory style, Hillsdale, NJ: Erlbaum, 1995. 
[28] M. Rijavec, D. Miljković and I. Brdar, Pozitivna psihologija: znanstveno istraživanje ljudskih snaga i sreće [Positive Psychology: The scientific research of character strengths and happiness], Zagreb: IEP-D, 2008.

[29] R. B. Kline, Principles and Practice of Structural Equation Modeling (3th ed.), New York, NY: The Guilford Press, 2011.

[30] P. Babcock and M. Marks, "The Falling Time Cost of College: Evidence from Half a Century of Time Use Data," Review of Economics and Statistics, vol. 93, no. 2, pp. 468-478, 2011. https://doi.org/10.1162/REST_a_00093

[31] E. L. Boyer, Scholarship reconsidered: Priorities of the professoriate, Princeton, N.J.: The Carnegie Foundation for the Advancement of Teaching, 1990.

[32] G. D. Kuh, "What We're Learning About Student Engagement From NSSE: Benchmarks for Effective Educational Practices," Change: The Magazine of Higher Learning, vol. 35, no. 2, pp. 24-32, 2003. https://doi.org/10.1080/00091380309604090

[33] C. R. Snyder, H. S. Shorey, J. Cheavens, K. M. Pulvers, V. H. Adams III and C. Wiklund, "Hope and Academic Success in College," Journal of Educational Psychology, vol. 94, no. 4, p. 820-826, 2002. https://doi.org/10.1037/0022-0663.94.4.820

[34] S. C. Marques, M. W. Gallagher and S. J. Lopez, "Hope- and academic-related outcomes: A meta-analysis," School Mental Health, vol. 9, no. 3, p. 250-262, 2017. https:/ /doi.org/10.1007/s12310-017-9212-9

[35] R. Bates and S. Khasawneh, "Self-efficacy and college students' perceptions and use of online learning systems," Computers in Human Behavior, vol. 27, no. 1, pp. 175-191, 2007. https://doi.org/10.1016/j.chb.2004.04.004

\section{Authors}

Tomislava Vidić has a $\mathrm{PhD}$ in Educational Sciences. She currently holds a position of a class teacher, with a teacher-counsellor title. As a lecturer at the Faculty of Teacher Education, University of Zagreb, she teaches the following courses: Classroom Management, Theory of Education, and Communication in Education. She has participated in several international conferences and published research papers and books.

Irena Klasnić is Assistant Professor at the Faculty of Teacher Education, Department of Education, University of Zagreb, the Republic of Croatia. Her professional and research interest are focused on didactics, school pedagogy, family pedagogy and pedagogy of free time. She has published more than 30 papers and participated in numerous conferences. She is a co-author of a university coursebook (email: irena.klasnic@ufzg.hr).

Marina Đuranović is Associate Professor at the Faculty of Teacher Education, Department of Education, University of Zagreb, the Republic of Croatia. She teaches pedagogy and didactics at several teacher education faculties in Zagreb. She has published more than 40 papers, participated in conferences in Croatia and abroad, and has coauthored two books. The focus of her interest includes pedagogy, didactics and pedagogy of free time (email: marina.duranovic@ufzg.hr).

Article submitted 2021-10-13. Resubmitted 2021-11-12. Final acceptance 2021-11-15. Final version published as submitted by the authors. 